\title{
Design, Synthesis and Characterization of HIV-1 CA-Targeting Small Molecules: Conformational Restriction of PF74
}

\author{
Rajkumar Lalji Sahani ${ }^{1}{ }^{1}$, Raquel Diana-Rivero ${ }^{1}$, Sanjeev Kumar V. Vernekar ${ }^{1}$, Lei Wang ${ }^{1}$, Haijuan Du ${ }^{2,3}$, \\ Huanchun Zhang 2,3, Andres Emanuelli Castaner ${ }^{2,3}$, Mary C. Casey ${ }^{4}$, Karen A. Kirby 2,3 $\mathbb{D}$, Philip R. Tedbury ${ }^{2,3} \mathbb{D}$, \\ Jiashu Xie ${ }^{1}$, Stefan G. Sarafianos ${ }^{2,3}$ and Zhengqiang Wang ${ }^{1, *(\mathbb{D})}$
}

1 Center for Drug Design, College of Pharmacy, University of Minnesota, Minneapolis, MN 55455, USA; rsahani@umn.edu (R.L.S.); raquel.diana.rivero@gmail.com (R.D.-R.); vvsanjeev99@gmail.com (S.K.V.V.); leiwang@dlut.edu.cn (L.W.); jxie@umn.edu (J.X.)

2 Laboratory of Biochemical Pharmacology, Department of Pediatrics, Emory University School of Medicine, Atlanta, GA 30322, USA; haijuan.du@emory.edu (H.D.); huanchun.zhang@emory.edu (H.Z.); andres.emanuelli@emory.edu (A.E.C.); karen.kirby@emory.edu (K.A.K.); philip.tedbury@emory.edu (P.R.T.); stefanos.sarafianos@emory.edu (S.G.S.)

3 Children's Healthcare of Atlanta, Atlanta, GA 30322, USA

4 Department of Molecular Microbiology and Immunology, School of Medicine, Christopher S. Bond Life Sciences Center, University of Missouri, Columbia, MO 65211, USA; mcc6x2@mail.missouri.edu

* Correspondence: wangx472@umn.edu; Tel.: +1-612-626-7025

\section{check for} updates

Citation: Sahani, R.L.; Diana-Rivero, R.; Vernekar, S.K.V.; Wang, L.; Du, H.; Zhang, H.; Castaner, A.E.; Casey, M.C.; Kirby, K.A.; Tedbury, P.R.; et al. Design, Synthesis and

Characterization of HIV-1

CA-Targeting Small Molecules: Conformational Restriction of PF74. Viruses 2021, 13, 479. https:// doi.org/10.3390/v13030479

Academic Editor: Gilda Tachedjian

Received: 11 February 2021

Accepted: 10 March 2021

Published: 15 March 2021

Publisher's Note: MDPI stays neutral with regard to jurisdictional claims in published maps and institutional affiliations.

Copyright: (c) 2021 by the authors. Licensee MDPI, Basel, Switzerland. This article is an open access article distributed under the terms and conditions of the Creative Commons Attribution (CC BY) license (https:/ / creativecommons.org/licenses/by/ $4.0 /)$.

\begin{abstract}
Small molecules targeting the PF74 binding site of the HIV-1 capsid protein (CA) confer potent and mechanistically unique antiviral activities. Structural modifications of PF74 could further the understanding of ligand binding modes, diversify ligand chemical classes, and allow identification of new variants with balanced antiviral activity and metabolic stability. In the current work, we designed and synthesized three series of PF74-like analogs featuring conformational constraints at the aniline terminus or the phenylalanine carboxamide moiety, and characterized them using a biophysical thermal shift assay (TSA), cell-based antiviral and cytotoxicity assays, and in vitro metabolic stability assays in human and mouse liver microsomes. These studies showed that the two series with the phenylalanine carboxamide moiety replaced by a pyridine or imidazole ring can provide viable hits. Subsequent SAR identified an improved analog $\mathbf{1 5}$ which effectively inhibited HIV-1 $\left(\mathrm{EC}_{50}=0.31 \mu \mathrm{M}\right)$, strongly stabilized CA hexamer $\left(\Delta \mathrm{Tm}=8.7^{\circ} \mathrm{C}\right)$, and exhibited substantially enhanced metabolic stability $\left(\mathrm{t}_{1 / 2}=27 \mathrm{~min}\right.$ for $15 \mathrm{vs}$. $0.7 \mathrm{~min}$ for PF74). Metabolic profiles from the microsomal stability assay also indicate that blocking the $\mathrm{C} 5$ position of the indole ring could lead to increased resistance to oxidative metabolism.
\end{abstract}

Keywords: HIV-1; capsid protein; PF74; conformational constraint; metabolic stability

\section{Introduction}

The capsid protein (CA) of human immunodeficiency virus type 1 (HIV-1), expressed as part of the viral Gag polyprotein, plays a critical role in multiple steps of the viral replication cycle [1]. In the late stage, CA-CA interactions drive the assembly of Gag polyproteins, and the reassembly of released CAs, toward immature and mature viral capsids, respectively [2]. In the early stage, productive HIV-1 infection entails numerous CA-mediated post-entry events [1] up to the completion of integration, including uncoating, cytoplasmic trafficking, reverse transcription, nuclear import, and integration site targeting. These events typically involve CA binding by host proteins, such as nucleoporin 153 (NUP153) [3] and cleavage and polyadenylation specificity factor 6 (CPSF6) [4,5], both of which are required for the nuclear import of HIV-1 pre-integration complexes (PICs). CPSF6 is also required for viral integration site targeting [6,7]. In addition, the CA-cyclophilin A (CypA) interaction allows HIV-1 to evade restriction by host factor tripartite motifcontaining protein 5 alpha (TRIM5a) [8]. Therefore, CA-targeting small molecules could 
inhibit viral replication via two distinct mechanisms of action: by disrupting CA-CA interactions, they could alter the overall core stability and impact viral assembly and uncoating; by competing against NUP153 and CPSF6 for CA binding, they could block viral nuclear entry and/or productive integration. These mechanisms, along with CA as an antiviral target, have been strongly validated with a few chemically distinct CA-targeting small molecule chemotypes [9], including mainly BI-2 [10], BM-4, BD-3 [11], CAP-1 [12], PF74 [13], GS-6207 (lenacapavir) [14,15]. Structurally, the CA monomer contains two primarily helical domains: the N-terminal domain $\left(\mathrm{CA}_{\mathrm{NTD}}\right)$ comprised of seven alphahelices H1-7, and the C-terminal domain (CA ${ }_{\text {CTD }}$ ) consisted of four alpha-helices H8$11[16,17]$. Reported CA-binding compounds predominantly target the CA $\mathrm{ATD}_{\mathrm{N}}$ where multiple binding sites have been identified. Amongst these, the PF74 binding pocket [17] is particularly well-characterized and significant. PF74 binds to the interface formed between the $\mathrm{H} 3$ and $\mathrm{H} 4$ of $\mathrm{CA}_{\mathrm{NTD}}$ and the $\mathrm{H} 8$ and $\mathrm{H} 9$ of the adjacent $\mathrm{CA}_{\mathrm{CTD}}$ within a CA hexamer (Figure 1A) $[13,17]$. In this binding pocket, PF74 interacts with N57 of H3 through the carbonyl-O4 and N(2)-H of the phenylalanine moiety (Figure 1C), K70 and Q63 of H4 through the other carbonyl-O3 and the indole $\mathrm{N}(1)-\mathrm{H}$, and several other residues, N53, M66, A105, T107, and Y130, though hydrophobic interactions (Figure 1A). Two other CA-targeting chemotypes, BI-2 [10] and GS-6207 [14,15], also bind to the same pocket, with very similar backbone binding (Figure 1B), despite their hugely different structural complexities (Figure 1C). Furthermore, the PF74 binding site also accommodates CPSF6 and NUP153, the host factors required for nuclear entry and integration site targeting of viral PICs (Figure 1D) [18]. Therefore, small molecules targeting this binding pocket can interfere with both early and late events of viral replication, and confer unique antiviral profiles with a bimodal mechanism of action, as manifested with PF74 and GS-6207 [19].

Although GS-6207 is far superior in antiviral potency to PF74, it lacks sufficient aqueous solubility to be an oral drug. Furthermore, mutations conferring resistance to GS-6207 have been selected in vitro [14,15]. One of the mutations that appeared in vitro, Q67H, was reported in recent clinical trials to be present in a patient sample, after nine days of treatment with GS-6207 [14]. On the other hand, PF74 suffers from extremely low metabolic stability [20-23]. These deficiencies necessitate continued medicinal chemistry efforts in identifying additional chemotypes targeting the PF74 pocket. For this purpose, the structural simplicity of PF74 offers a distinct synthetic chemistry advantage over GS-6207 for chemical modifications. We have previously pursued the design and synthesis of PF74like compounds and have identified several subtypes with improved antiviral potency and/or enhanced metabolic stability [20-23]. The current work studies the impact of overall molecular rigidity on CA targeting and metabolic stability. The primary rationale is that binding to a protein typically results in the conformational/configurational restriction of a ligand, and hence, an entropy loss that needs to be compensated for, the amount of which will be reduced if the ligand is conformationally restricted to begin with [24]. The importance of rigidity in small molecule inhibitor design has been demonstrated [25,26]. In addition, PF74 features an aniline $N$-methyl group, which is a well-known metabolic handle $[27,28]$ and a likely culprit of the poor metabolic stability of PF74. In our redesign of PF74 (Figure 2), rigidity is introduced either to the aniline moiety by capping the N-methyl and the ortho-phenyl end of PF74 (modification A, chemotype 1), or to the phenylalanine amide moiety by capping the $N$-methyl and the amide carbonyl (modification $\mathrm{B}$, chemotype 2 and chemotype 3). The subsequent structure-activity relationship (SAR) also explores previously reported $[20,22]$ key interactions, such as halogen bonding conferred by the para-halogen (Figure 2, $\mathrm{R}^{1}$ ) of the aniline phenyl to N74, hydrophobic interaction by the indole $\mathrm{N}$-Et $\left(\mathrm{R}^{4}\right)$, and H-bonding by the indole $\mathrm{C} 5-\mathrm{OH}\left(\mathrm{R}^{3}\right)$ to $\mathrm{K} 182$ of the adjacent CACTD. 


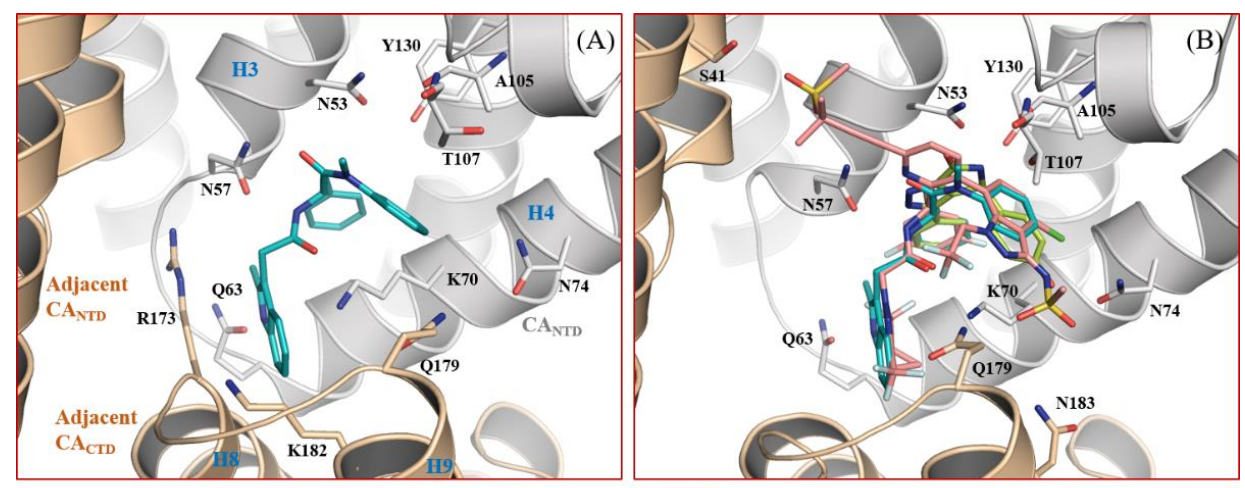

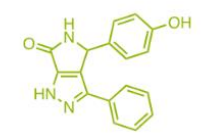

BI-2

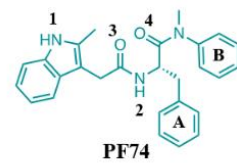

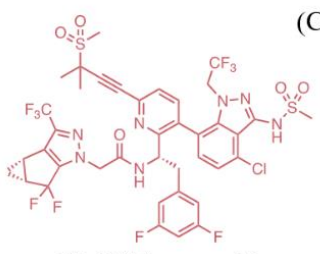

GS-6207 (lenacapavir)

ACE PVLFPGQPFGQPPL NMA CPSF6 derived peptide
(C)

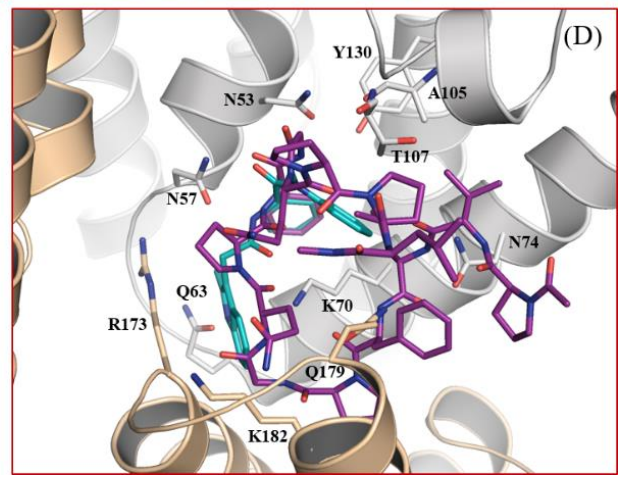

Figure 1. Structure of HIV-1 capsid protein (CA) and key CA-ligand and -host binding pocket. (A) Binding of PF74 on HIV-1 capsid protein (PDB code: 4XFZ [17]). PF74 occupies a binding pocket formed around alpha-helices H3 and H4 in CA (grey) and H8 and H9 in adjacent CA $\mathrm{C}_{\mathrm{CD}}$ (orange). Two other CA-targeting small molecule chemotypes, BI-2 [10] and GS-6207 [14,15], as well as host proteins CPSF6 and NUP153 [18], also occupy this same pocket; (B) superimposition of PF74, BI-2, and GS-6207 in the same binding pocket; (C) chemical structures of PF74, BI-2 and GS-6207, and amino acid sequence of host protein CPSF6 derived peptide. The boxed (cyan) phenylalanine residue corresponds with the phenylalanine moiety of PF74 in the binding pocket; (D) superimposition of PF74 and CPSF6 derived peptide (PDB code: 4U0A [18]) in the same binding pocket.

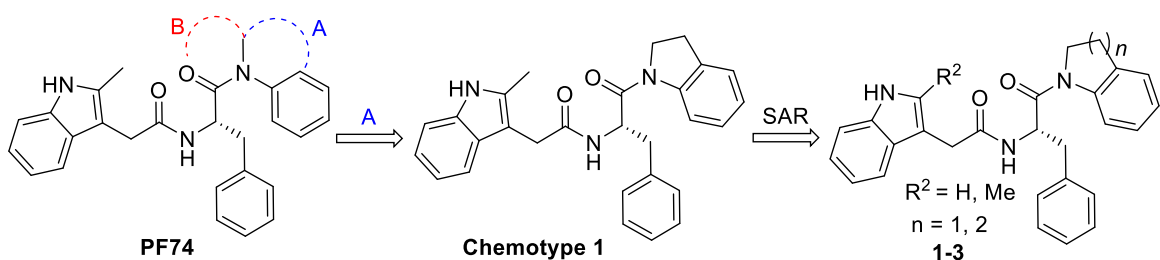<smiles>C=CCCCCCCCCCCCCCCCCCC(=O)NC(Cc1ccccc1)c1ncccc1-c1ccccc1</smiles><smiles>Cc1[nH]c2ccccc2c1CC(=O)N[C@H](Cc1ccccc1)c1nccn1-c1ccccc1</smiles><smiles>[R]c1ccc(-n2ccnc2C(Cc2ccccc2)NC(=O)Cc2c([R])[nH]c3ccc([R])cc23)cc1</smiles><smiles></smiles>

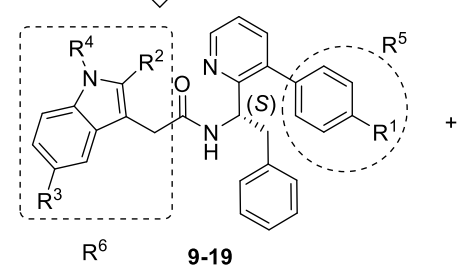

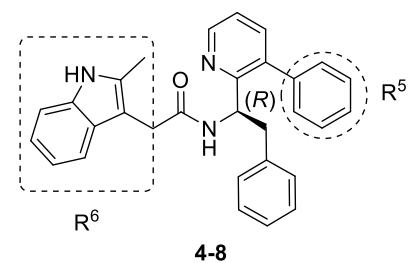

Figure 2. Design of conformationally constrained chemotypes based on PF74. 


\section{Materials and Methods}

\subsection{Chemistry}

All tested analogs were synthesized as described in Schemes 1-3, and were fully characterized with ${ }^{1} \mathrm{H}$ and ${ }^{13} \mathrm{C}$ NMR, and HRMS. Synthetic procedures and compound characterization data are included in Supplementary Materials. The general synthetic strategies for major analogs (1-25) tested in this work are described here (Schemes 1-3) and the synthesis of other intermediates is outlined in supporting information (Supplementary Schemes S1-S3).<smiles>[R]c1[nH]c2ccccc2c1CC(=O)NC(=O)C(Cc1ccccc1)NC(=O)Cc1c([R])[nH]c2ccccc12</smiles>

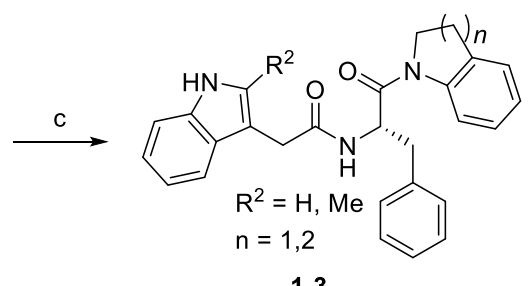

Scheme 1. Synthesis of analogs 1-3. Reagents and conditions: (a) L-phenylalanine methyl ester hydrochloride, HATU, DIPEA, DMF, rt, 12 h; (b) LiOH, THF, rt, 12 h; (c) amine, PyOAP, DIPEA, DMF, $\mathrm{rt}, 12 \mathrm{~h}$.

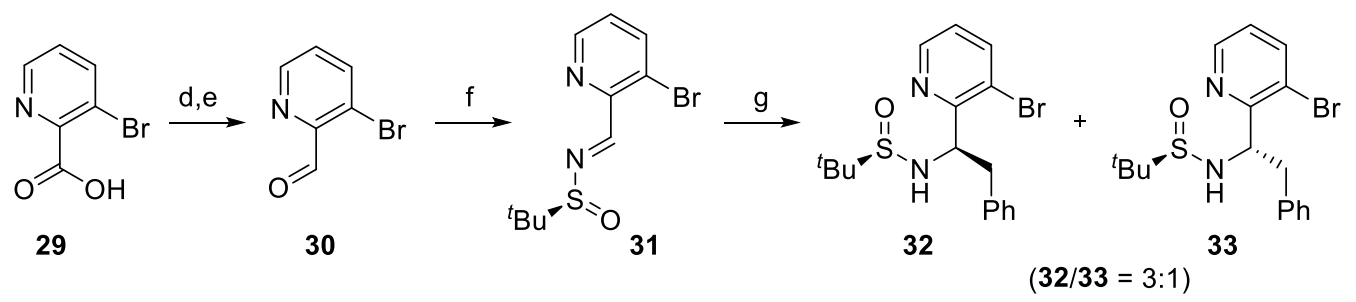

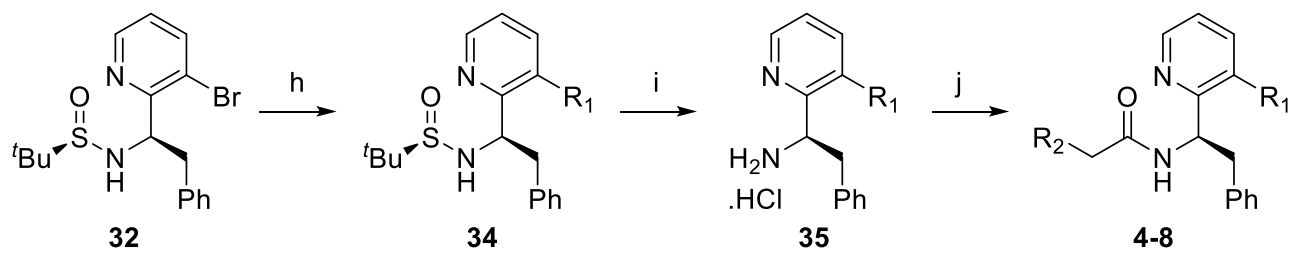

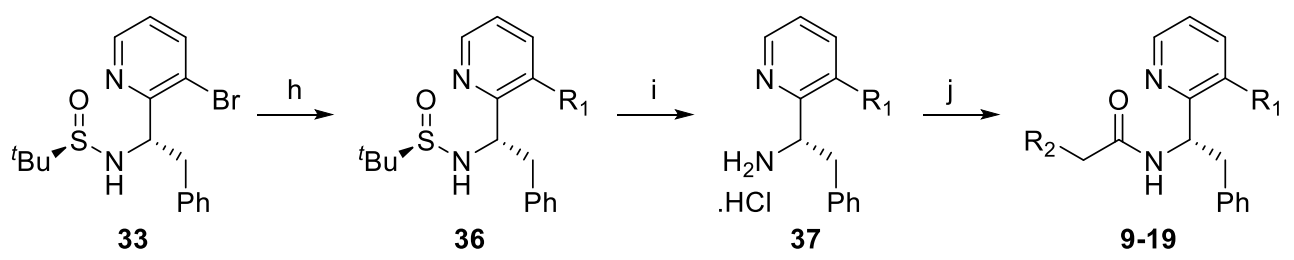

Scheme 2. Synthetic strategy for analogs 4-19. Reagents and conditions: (d) $(\mathrm{COCl})_{2}$, cat. DMF, DCM, $0{ }^{\circ} \mathrm{C}-\mathrm{rt}, 2 \mathrm{~h}$, then $\mathrm{MeOH}, \mathrm{rt}, 2 \mathrm{~h}$; (e) DIBAL-H, THF, $-78^{\circ} \mathrm{C}, 3 \mathrm{~h}$; (f) (R)-(+)-2-methyl-2-propanesulfinamide, $\mathrm{CuSO}_{4}, \mathrm{DCM}, \mathrm{rt}, 3 \mathrm{~h}$; (g) benzyl-magnesium chloride, $\mathrm{DCM},-78^{\circ} \mathrm{C}-\mathrm{rt}, 5 \mathrm{~h}$; (h) boronic acid, $\mathrm{Pd}\left(\mathrm{PPh}_{3}\right)_{2} \mathrm{Cl}_{2}, \mathrm{~K}_{2} \mathrm{CO}_{3}, \mathrm{DME}, \mathrm{MW}, 120^{\circ} \mathrm{C} 45$ min.; (i) $4 \mathrm{~N} \mathrm{HCl} /$ dioxane, $\mathrm{MeOH}$, rt, $1 \mathrm{~h}$; (j) acid, HATU or T3P, DIPEA, DMF, rt, $12 \mathrm{~h}$. 


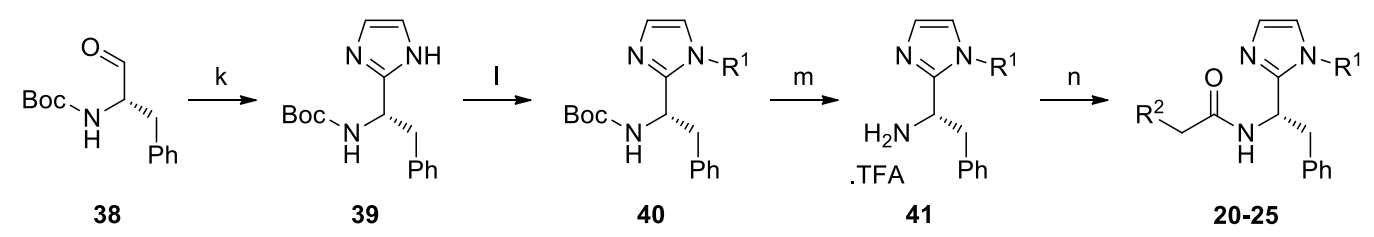

Scheme 3. Synthetic Strategy for Analogs 20-25. Reagents and conditions: (k) glyoxal, $\mathrm{NH}_{3}(\mathrm{~g}), \mathrm{MeOH},-78^{\circ} \mathrm{C}-\mathrm{rt}, 4$ days; (1) boronic acid, $\mathrm{Cu}(\mathrm{OAc})_{2}$, DIPEA, DCM, $4 \AA$ MS, rt, 4 days; (m) TFA, DCM, rt, 12 h; (n) acid, HATU, DIPEA, DMF, rt, 12 h.

Chemotype 1 was synthesized according to procedures describe in Scheme 1 [20]. Commercially available indole-acetic acids $\mathbf{2 6}$ were treated with commercially available L-Phenylalanine methyl ester hydrochloride under a well-established strategy using HATU in the presence of DIPEA to afford 27. $\mathrm{LiOH}$ hydrolysis of intermediates 27 afforded acid intermediates $\mathbf{2 8}$, which were further reacted with corresponding indoline or tetrahydroquinoline to give the desired compounds 1-3.

The synthesis of intermediates 30-37 and major analogs (4-19) was achieved using a route described in Scheme 2 [29,30]. Commercially available 3-bromopicolinic acid 29 was converted to 3-bromopicolinaldehyde 30 through oxalyl chloride/DMF assisted esterification, followed by DIBAL-H reduction. Intermediate $\mathbf{3 0}$ was then treated with commercially available $(R)-(+)-2-M e t h y l-2-$ propanesulfinamide to form sulfonimine 31, which was subjected to Grignard addition of benzyl-magnesium chloride to produce two diastereomers 32 and 33 in 3:1 ratio. Subsequently, intermediate 32 was subjected to Suzuki coupling with various boronic acids to produce intermediates 34 , which upon deprotection furnished intermediates 35 . Finally, intermediates 35 were reacted with corresponding acids with HATU in the presence of DIPEA to afford compounds 4-8. Similarly, the synthesis of analogs 9-19 was accomplished from intermediate 33 , with the exception of using $\mathrm{T}_{3} \mathrm{P}$ in place of HATU in the final amide-coupling reaction for the synthesis of compound 15.

Analogs 20-25 were synthesized as described in Scheme 3 [30]. The synthesis of intermediates 39-41 is discussed in detail in the supporting information (Scheme S3). Commercially available N-boc phenyl-alaninal $\mathbf{3 8}$ and glyoxal were treated with ammonia to construct imidazole ring intermediate 39 , which was subjected to copper catalyzed ChanLam reaction with various boronic acids to produce intermediate 40. TFA deprotection of Boc group resulted in intermediate $\mathbf{4 1}$, which was reacted with various indole-acetic acids using HATU in the presence of DIPEA to afford compounds 20-25.

\subsection{Cells}

TZM-GFP cells are a modified version of TZM-bl cells and contain an integrated nlsGFP reporter gene under the transcriptional control of the HIV-1 long terminal repeat (LTR) [31,32]; TZM-GFP cells produce GFP following infection with HIV-1. TZM-GFP cells were kindly provided by Dr. Marc Johnson (University of Missouri-Columbia, Columbia, MO, USA) and cultured in DMEM supplemented with $10 \%$ fetal bovine serum (FBS; Hyclone, Logan, UT, USA). HEK293-FT cells were cultured in DMEM supplemented with $10 \%$ FBS. MT-2 cells were grown in RPMI supplemented with $10 \%$ heat-inactivated FBS. All cells were grown and maintained in humidified atmosphere containing $5 \% \mathrm{CO}_{2}$ at $37^{\circ} \mathrm{C}$.

\subsection{Method Details}

\subsubsection{Thermal Shift Assays (TSAs) to Screen Compounds for Effect on HIV-1 CA Hexamer Stability}

Compounds were screened for binding using purified covalently-crosslinked hexameric CA ${ }^{\mathrm{A} 14 \mathrm{C} / \mathrm{E} 45 \mathrm{C} / \mathrm{W} 184 \mathrm{~A} / \mathrm{M} 185 \mathrm{~A}}$ (CA121). CA121 cloned in a pET11a expression plasmid was kindly provided by Dr. Owen Pornillos (University of Virginia, Charlottesville, VA, USA). Protein was expressed in E. coli BL21(DE3)RIL and purified as reported previously [33]. The TSA has been previously described [20-23]. Briefly, the TSA was conducted on the PikoReal Real-Time PCR System (Thermo Fisher Scientific, Waltham, MA, USA) or the 
QuantStudio 3 Real-Time PCR system (Thermo Fisher Scientific, Waltham MA, USA). Each reaction contained $7.5 \mu \mathrm{M}$ final concentration CA121, $1 \times$ Sypro Orange Protein Gel Stain (Life Technologies, Carlsbad, CA, USA) in $50 \mathrm{mM}$ sodium phosphate buffer (pH 8.0) and $1 \%$ DMSO (control) or $20 \mu \mathrm{M}$ compound in $1 \%$ DMSO. The plate was heated from 25 to $95{ }^{\circ} \mathrm{C}$ with a heating rate of $0.2{ }^{\circ} \mathrm{C} / 10 \mathrm{~s}$. The fluorescence intensity was measured with an Ex range of 475-500 $\mathrm{nm}$ and Em range of 520-590 $\mathrm{nm}$. The differences in the melting temperature $(\triangle \mathrm{Tm})$ of CA hexamer in DMSO $\left(\mathrm{T}_{0}\right)$ verses in the presence of compound $(\mathrm{Tm})$ were calculated using the following formula: $\Delta \mathrm{Tm}=\mathrm{Tm}-\mathrm{T}_{0}$.

\subsubsection{Virus Production}

The wild-type laboratory HIV-1 strain, HIV-1 $1_{\text {NL4-3 }}$ [34], was produced using a pNL4-3 vector that was obtained through the NIH AIDS Reagent Program, Division of AIDS, NIAID, NIH. HIV-1NL4-3 was generated by transfecting HEK 293FT cells in a $10 \mathrm{~cm}$ tissue culture dish with $10 \mu \mathrm{g}$ of the pNL4-3 vector and X-tremeGENE HP DNA Transfection Reagent (Roche, Indianapolis, IN, USA), following the manufacturer's protocol. Supernatant was harvested $48-72 \mathrm{~h}$ post-transfection. The viral supernatant was then concentrated using Lenti-X Concentrator (Takara, Mountain View, CA, USA), following the manufacturer's protocol. The resulting viral-containing pellet was concentrated 10-fold by resuspension in DMEM without FBS and stored at $-80^{\circ} \mathrm{C}$.

\subsubsection{Anti-HIV-1 and Cytotoxicity Assays}

Anti-HIV-1 activity of PF74 and PF74-related analogs were examined in TZM-GFP cells. The potency of HIV-1 inhibition by a compound was based on its inhibition of HIV-1 infection of TZM-GFP cells compared with that of compound-free (DMSO) controls. Briefly, TZM-GFP cells were plated at a density of $1 \times 10^{4}$ cells per well in a 96-well plate. $24 \mathrm{~h}$ later, medium was replaced with medium containing compound dilutions. $24 \mathrm{~h}$ post treatment, cells were exposed to HIV-1 $1_{\mathrm{NL} 4-3}(\mathrm{MOI}=0.1)$. After incubation for $48 \mathrm{~h}$, antiHIV-1 activity was assessed by counting the number of GFP positive cells on a Cytation 5 Imaging Reader (BioTek, Winooski, VT, USA) and 50\% effective concentration ( $\mathrm{EC}_{50}$ ) values were determined.

Cytotoxicity of each compound was also determined in TZM-GFP cells. Cells were plated at a density of $1 \times 10^{4}$ cells per well in a 96-well plate and were continuously exposed to medium containing compound dilutions for $72 \mathrm{~h}$. Cell viability was determined using a Cell Proliferation Kit II (XTT), and 50\% cytotoxicity concentration $\left(\mathrm{CC}_{50}\right)$ values were determined. All the cell-based assays were conducted with technical duplicates and with at least two independent experiments and the average values were determined.

For the $\mathrm{EC}_{50}$ and $\mathrm{CC}_{50}$ dose responses, values were plotted in GraphPad Prism 5 and analyzed with the $\log$ (inhibitor) vs. normalized response-variable slope equation. Final values were calculated in each independent assay and the average values were determined. Statistical analysis (calculation of standard deviation) was performed using Microsoft Excel.

\subsection{Metabolic Stability Assay}

Microsomal stability. The in vitro microsomal stability assay was conducted in triplicate in mouse and human liver microsomal systems, which were supplemented with nicotinamide adenine dinucleotide phosphate (NADPH) as a cofactor. Briefly, a compound $(1 \mu \mathrm{M}$ final concentration) was spiked into the reaction mixture containing liver microsomal protein $\left(0.5 \mathrm{mg} / \mathrm{mL}\right.$ final concentration) and $\mathrm{MgCl}_{2}$ ( $1 \mathrm{mM}$ final concentration) in $0.1 \mathrm{M}$ potassium phosphate buffer ( $\mathrm{pH}$ 7.4). The reaction was initiated by addition of $1 \mathrm{mM}$ $\mathrm{NADPH}$, followed by incubation at $37^{\circ} \mathrm{C}$. A negative control was performed in parallel without NADPH to reveal any chemical instability or non-NADPH dependent enzymatic degradation for each compound. At various time points $(0,5,15,30$ and $60 \mathrm{~min}), 1$ volume of reaction aliquot was taken and quenched with 3 volumes of acetonitrile containing $0.1 \%$ formic acid. The samples were then vortexed and centrifuged at 15,000 rpm for $5 \mathrm{~min}$ 
at $4{ }^{\circ} \mathrm{C}$. The supernatants were collected and analyzed by LC/MS/MS to determine the remaining percentage and in vitro metabolic half-life $\left(t_{1 / 2}\right)$.

\subsection{Molecular Modeling}

Molecular modeling was performed using the Schrödinger small molecule drug discovery suite 2019-4 [35]. The crystal structure of PF74 [17] in complex with native HIV-1 capsid protein was retrieved from the protein data bank (PDB code: 4XFZ [17]). Selected structures were evaluated for their interaction with native HIV-1 capsid protein using Maestro [36] (Schrödinger; LLC: New York, NY, USA) by subjecting to a docking protocol, involving preparing protein of interest, grid generation, ligand preparation, and docking. Post processing of each docked pose was done by PyMOL [37] (Schrödinger; LLC: New York, NY, USA). The native HIV-1 capsid protein/PF74 crystal structure was refined using the protein preparation wizard [38] (Schrödinger; LLC: New York, NY, USA) in which missing hydrogen atoms, side chains, and loops were added using Prime; waters beyond $5 \AA$ were deleted, and minimized using the OPLS3e force field [39] to optimize the hydrogen bonding network and converge the heavy atoms to an RMSD of $0.3 \AA$. The active site around the native ligand PF74 was defined by the receptor grid generation tool in Maestro (Schrödinger; LLC: New York, NY, USA) covering all the residues within $12 \AA$. All the compounds were drawn using 2D-sketcher in Maestro and subjected to LigPrep to generate conformers and possible protonation at $\mathrm{pH}$ of $7 \pm 2$. All the dockings were performed using Glide XP [40] (Glide, version 8.2) with the van der Waals radii of nonpolar atoms for each of the ligands scaled by a factor of 0.8 to decrease penalties for close contacts. All docked poses were subjected to post-docking minimization (PMD) to minimize a small number of poses within the field of the receptor to produce better poses. The residue numbers of HIV-1 capsid protein used in the discussion and the figures were based on the native HIV-1 capsid protein.

\section{Results}

Analogs synthesized for each series were first tested in a biophysical thermal shift assay (TSA), which measures how compounds affect the stability of covalently crosslinked CA hexamers. TSA results are presented as the change of protein melting temperature in the presence of a compound compared to the protein melting temperature in the presence of DMSO control $(\Delta \mathrm{Tm})$. A right shift (positive $\Delta \mathrm{Tm}$ ) denotes a stabilizing effect, whereas a left shift (negative $\Delta \mathrm{Tm}$ ) indicates a destabilizing effect. All final compounds were also tested in cell-based assays to determine anti-HIV-1 activity and cytotoxicity. The initial antiviral screening was conducted at $20 \mu \mathrm{M}$, from which compounds showing significant inhibition were further tested in a dose-response assay to determine antiviral $\mathrm{EC}_{50}$ values. $\mathrm{CC}_{50}$ values were determined by cytotoxicity assay. The parent PF74 was used as a control in these assays $\left(\Delta \mathrm{Tm}=6.9^{\circ} \mathrm{C}, \mathrm{EC}_{50}=0.70 \mu \mathrm{M}, \mathrm{CC}_{50}=76 \mu \mathrm{M}\right)$. Selected compounds were also tested for metabolic stability in liver microsomes. Molecular modeling was performed for a few analogs to corroborate the binding modes and understand the SAR.

\subsection{The Indoline and Quinoline Analogs (Chemotype 1)}

This short series sought to explore the effect of rigidifying the terminal $\mathrm{N}$-methyl aniline. As shown in Table 1, cyclization of the $N$-methyl to the ortho position of the phenyl ring via a five-membered or six-membered ring is not tolerated as the resulting analogs 1-3 showed no significant antiviral activity or CA-stabilizing/destabilizing effect. This is likely to be due to the loss of an important van der Waals interaction of the $N$-methyl group with the side chain of N53 [20]. 
Table 1. Anti-HIV-1 activity, cytotoxicity, and CA hexamer stability profiles of chemotype 1.

\begin{tabular}{|c|c|c|c|c|}
\hline Cpd & Structure & $\mathrm{EC}_{50}(\mu \mathrm{M})^{\mathrm{a}}$ & $\mathrm{CC}_{50}(\mu \mathrm{M})^{\mathrm{b}}$ & $\operatorname{TSA} \Delta \operatorname{Tm}\left({ }^{\circ} \mathrm{C}\right)$ \\
\hline PF74 & & $0.70 \pm 0.07$ & $76 \pm 9$ & $6.9 \pm 0.5$ \\
\hline 1 & & $>20$ & $>100$ & -0.5 \\
\hline 2 & & $>20$ & $>100$ & -1.0 \\
\hline 3 & & $>20$ & $>50$ & $1.8 \pm 1.2$ \\
\hline
\end{tabular}

${ }^{a}$ Concentration of compound inhibiting HIV-1 replication by $50 \%$, expressed as the mean \pm standard deviation from at least two independent experiments. ${ }^{\mathrm{b}}$ Concentration of compound causing $50 \%$ cell death, expressed as the mean \pm standard deviation from at least two independent experiments. ${ }^{\mathrm{c}} \mathrm{TSA}$ : thermal shift assay. $\Delta \mathrm{Tm}$ : change of CA crosslinked hexamer melting temperature in the presence of compound minus melting temperature of CA crosslinked hexamer in the presence of DMSO (control).

\subsection{SAR of the Pyridine Series (Chemotype 2)}

This chemotype features a key backbone conformational constraint conceived via building the phenylalanine carboxamide into a pyridine ring (Figure 2, modification B). Incidentally, such a design resulted in a phenylalanine mimic similar to the core of GS-6207 (Figure 1C). The prototype of this chemotype, analog 9 (Table 2), considerably inhibited HIV-1 $\left(\mathrm{EC}_{50}=2.6 \mu \mathrm{M}\right)$ and strongly stabilized CA hexamer $\left(\Delta \mathrm{Tm}=4.5^{\circ} \mathrm{C}\right)$. In stark contrast, the enantiomer of 9 , the $R$-phenylalanine derived analog 4 , was completely inactive in both the antiviral assay and the TSA (Table 2). This dramatic SAR trend was largely retained as additional $R$-configured analogs (5-8) showed neither CA-stabilizing nor destabilizing effect, and they lacked significant antiviral activity, whereas $S$-configured analogs 10-19 all inhibited HIV-1 at low to sub-micromolar concentrations (Table 2). The stereochemical requirement of the $S$ configuration (Figure 2) is not unexpected since the phenyl ring of the phenylalanine serves as an anchor for ligand and host factor binding [41]. Among the $S$-configured analogs, the ones with an indazole (10) or a pyrazole (11) in place of an indole only weakly stabilized CA hexamers, and both inhibited HIV-1 at low micromolar $\mathrm{EC}_{50}$ concentrations. By contrast, with the exception of 12, all indole analogs (13-19) strongly stabilized CA-hexamers $\left(\Delta \mathrm{Tm}=5.9-8.7^{\circ} \mathrm{C}\right)$. Notably, having a chlorine atom at the para position of the terminal phenyl ring (13-15) appeared to benefit both the antiviral activity and the CA-stabilizing effect, which may reflect halogen bonding with the CA-protein $[22,23]$. The $\mathrm{OH}$ group at the indole $\mathrm{C} 5$ position also conferred improved potency and CA-stabilizing effect (15 vs. 13), though the $\mathrm{OH}$ effect was not as prominent as observed with PF74 analogs [22]. In the latter case, $\mathrm{OH}$ is believed to form an $\mathrm{H}$-bond with the $\mathrm{K} 182$ of the adjacent $\mathrm{CA}_{\mathrm{CTD}}$. When the indole $\mathrm{N}$ is ethylated, the resulting analogs were considerably less active (16 vs. 13, 17 vs. 14), which amounts to a reversed SAR trend compared to PF74 analogs [20]. Interestingly, significant difference was not observed between $\mathrm{Br}$ and $\mathrm{Cl}$ (19 vs. 16, 18 vs. 17). Finally, compounds with a halogen (13-19) of this series were all somewhat cytotoxic. Overall, $\mathbf{1 5}$ was the most potent compound of this series $\left(\mathrm{EC}_{50}=0.31 \mu \mathrm{M}\right.$, Table 2 and Figure 3$)$, with a better selectivity index (SI) over the 
parent PF74 (SI = 142 for 15 vs. 109 for PF74). A Wilcoxon rank-sum test was performed to determine the significance of the $\mathrm{EC}_{50}$ value of compound 15 compared to the $\mathrm{EC}_{50}$ value of the parent PF74 compound $\left(\mathrm{EC}_{50}=0.7 \mu \mathrm{M}\right)$. The $p$-value $=0.029$, which demonstrates that difference between these two samples is statistically significant.

Table 2. Anti-HIV-1 activity, cytotoxicity, and CA hexamer stability profiles of chemotype 2.

\begin{tabular}{|c|c|c|c|c|}
\hline $\mathrm{Cpd}^{\mathrm{d}}$ & Structure & $\mathrm{EC}_{50}(\mu \mathrm{M})^{\mathrm{a}}$ & $\mathrm{CC}_{50}(\mu \mathrm{M})^{\mathrm{b}}$ & $\operatorname{TSA} \Delta \operatorname{Tm}\left({ }^{\circ} \mathrm{C}\right)^{\mathrm{c}}$ \\
\hline PF74 & & $0.70 \pm 0.07$ & $76 \pm 9$ & $6.9 \pm 0.5$ \\
\hline 4 & & $>20$ & $<50$ & $0.1 \pm 0.1$ \\
\hline 5 & & $>20$ & $<50$ & $0.1 \pm 0.07$ \\
\hline 6 & & $>15$ & $>50$ & $0.3 \pm 0.1$ \\
\hline 7 & & $>20$ & $>50$ & $0 \pm 0$ \\
\hline 8 & & $>20$ & $>50$ & $0.1 \pm 0.1$ \\
\hline 9 & & $2.6 \pm 0.4$ & $<50$ & $4.5 \pm 0.0$ \\
\hline 10 & & $8.8 \pm 0.4$ & $<50$ & $1.0 \pm 0.07$ \\
\hline 11 & & $5.1 \pm 0.7$ & $>50$ & $1.1 \pm 0.07$ \\
\hline
\end{tabular}


Table 2. Cont.

\begin{tabular}{|c|c|c|c|c|}
\hline $\operatorname{Cpd}^{d}$ & Structure & $\mathrm{EC}_{50}(\mu \mathrm{M})^{\mathrm{a}}$ & $\mathrm{CC}_{50}(\mu \mathrm{M})^{\mathrm{b}}$ & $\operatorname{TSA} \Delta \operatorname{Tm}\left({ }^{\circ} \mathrm{C}\right)^{\mathrm{c}}$ \\
\hline 12 & & $>20$ & $>50$ & $-0.2 \pm 0.07$ \\
\hline 13 & & $0.79 \pm 0.25$ & $22 \pm 2$ & $7.7 \pm 0.2$ \\
\hline 14 & & $1.4 \pm 0.7$ & $39 \pm 0.2$ & $7.8 \pm 0.3$ \\
\hline $15^{d}$ & & $0.31 \pm 0.07$ & $44 \pm 1$ & $8.7 \pm 0.3$ \\
\hline 16 & & $2.7 \pm 0.2$ & $41 \pm 0.1$ & $6.6 \pm 0.2$ \\
\hline 17 & & $3.6 \pm 0.2$ & $48 \pm 6$ & $5.9 \pm 0.2$ \\
\hline 18 & & $2.1 \pm 0.8$ & $40 \pm 4$ & $6.3 \pm 0.6$ \\
\hline 19 & & $3.2 \pm 0.3$ & $41 \pm 2$ & $6.3 \pm 0.1$ \\
\hline
\end{tabular}

${ }^{a}$ Concentration of compound inhibiting HIV-1 replication by $50 \%$, expressed as the mean \pm standard deviation from at least two independent experiments. ${ }^{\mathrm{b}}$ Concentration of compound causing $50 \%$ cell death, expressed as the mean \pm standard deviation from at least two independent experiments. ${ }^{\mathrm{c}} \mathrm{TSA}$ : thermal shift assay. $\triangle \mathrm{Tm}$ : change of CA crosslinked hexamer melting temperature in the presence of compound minus melting temperature of CA crosslinked hexamer in the presence of DMSO (control). ${ }^{\mathrm{d}} \mathrm{SI}$ (selectivity index $=\mathrm{CC}_{50} / \mathrm{EC}_{50}$ ): 109 (PF74), 142 (15). 


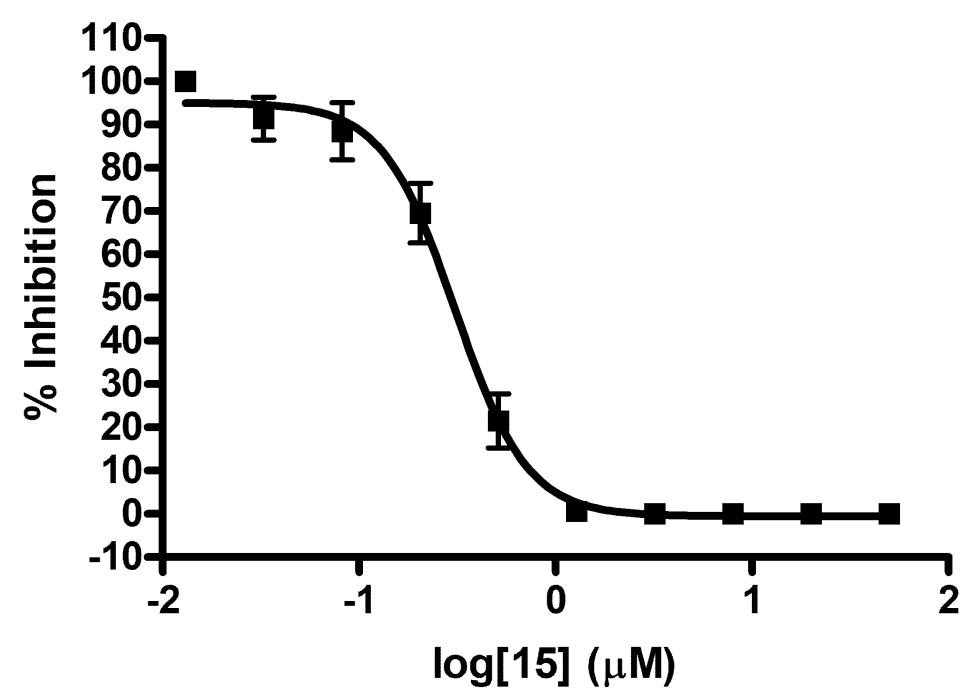

Figure 3. Dose-response curve of the best compound, 15. Values are represented as mean of four independent experiments, with standard error bars shown. Data were analyzed as nonlinear regression, sigmoidal dose-response (variable slope) curve fit in GraphPad Prism.

\subsection{SAR of the Imidazole Series (Chemotype 3)}

This series was designed by converting the phenylalanine carboxamide moiety into an imidazole ring for achieving backbone conformational constraint. Similar to the pyridine series (chemotype 2), the PF74-derived prototypical imidazole analog 20 displayed significant antiviral activity $\left(\mathrm{EC}_{50}=3.7 \mu \mathrm{M}\right)$ and strong CA-stabilizing effect $\left(\Delta \mathrm{Tm}=3.9^{\circ} \mathrm{C}\right)$. However, subsequent SAR did not yield improved compounds, with analogs 21, 23-25 all showing similar activity profiles (Table 3). The single exception is compound $\mathbf{2 2}$ featuring a para-tetrazole group on the terminal phenyl ring, which conferred no antiviral activity. Interestingly, halogenated analogs within this series (23-25) were substantially less cytotoxic than the pyridine series (13-19).

Table 3. Anti-HIV-1 activity, cytotoxicity, and CA hexamer stability profiles of chemotype 3.

\begin{tabular}{|c|c|c|c|c|}
\hline Cpd & Structure & $\mathrm{EC}_{50}(\mu \mathrm{M})^{\mathrm{a}}$ & $\mathrm{CC}_{50}(\mu \mathrm{M})^{\mathrm{b}}$ & $\operatorname{TSA} \Delta \operatorname{Tm}\left({ }^{\circ} \mathrm{C}\right)^{\mathrm{c}}$ \\
\hline PF74 & & $0.70 \pm 0.07$ & $76 \pm 9$ & $6.9 \pm 0.5$ \\
\hline 20 & & $3.7 \pm 0.8$ & $>50$ & $3.9 \pm 0.4$ \\
\hline 21 & & $6.6 \pm 0.4$ & $>50$ & $2.2 \pm 0.0$ \\
\hline 22 & & $>20$ & $>50$ & $-0.3 \pm 0.1$ \\
\hline
\end{tabular}


Table 3. Cont.

\begin{tabular}{|c|c|c|c|c|}
\hline Cpd & Structure & $\mathrm{EC}_{50}(\mu \mathrm{M})^{\mathrm{a}}$ & $\mathrm{CC}_{50}(\mu \mathrm{M})^{\mathrm{b}}$ & $\operatorname{TSA} \Delta \operatorname{Tm}\left({ }^{\circ} \mathrm{C}\right){ }^{\mathrm{c}}$ \\
\hline 23 & & $3.3 \pm 0.03$ & $93 \pm 2$ & $4.0 \pm 0.3$ \\
\hline 24 & & $3.5 \pm 0.3$ & $>100$ & $2.8 \pm 0.3$ \\
\hline 25 & & $3.3 \pm 0.2$ & $>100$ & $2.7 \pm 0.1$ \\
\hline
\end{tabular}

${ }^{\text {a }}$ Concentration of compound inhibiting HIV-1 replication by 50\%, expressed as the mean \pm standard deviation from at least two independent experiments. ${ }^{b}$ Concentration of compound causing $50 \%$ cell death, expressed as the mean \pm standard deviation from at least two independent experiments. ${ }^{\mathrm{C}}$ TSA: thermal shift assay. $\Delta \mathrm{Tm}$ : change of CA crosslinked hexamer melting temperature in the presence of compound minus melting temperature of CA crosslinked hexamer in the presence of DMSO (control).

\subsection{Metabolic Stability}

A major deficiency of PF74 as an antiviral compound is the extremely low metabolic stability [42-44], with half-life $\left(t_{1 / 2}\right)$ less than $1 \mathrm{~min}$ in both human liver microsomes (HLMs) and mouse liver microsomes (MLMs) [20-23]. Our previous work also revealed that this is mainly due to the poor resistance to cytochrome P450 3A4 (CYP3A4)-mediated oxidative metabolism, as the half-life was drastically elongated in the presence of a CYP3A4 inhibitor [20-23]. To assess the impact of conformational restriction on the susceptibility toward CYP3A4, we tested seven selected analogs in the microsomal stability assay. Overall, very poor microsomal stability was observed with these analogs (Table 4), suggesting that conformationally constrained analogs remain good substrates [45] for CYP3A4, as are many peptidomimetics, including PF74. A notable exception was analog $15\left(t_{1 / 2}=27 \mathrm{~min}\right)$ which contains a $\mathrm{OH}$ group at the $\mathrm{C} 5$ position of the indole ring.

Table 4. Phase I metabolic stability in liver microsomes $\mathrm{t}_{1 / 2}$ (min).

\begin{tabular}{cccc}
\hline Cpd & HLMs $^{\text {a }}$ & MLMs $^{\mathbf{b}}$ & Metabolite (s) $^{\mathbf{b}^{\mathrm{c}}}$ \\
\hline PF74 & $0.7^{\mathrm{c}}$ & $0.6^{\mathrm{c}}$ & - \\
$\mathbf{9}$ & $1.2 \pm 0.04$ & $1.0 \pm 0.01$ & - \\
$\mathbf{1 4}$ & $1.7 \pm 0.02$ & $0.9 \pm 0.004$ & $\mathbf{1 5}$ \\
$\mathbf{1 5}$ & $27.2 \pm 0.5$ & $3.1 \pm 0.3$ & - \\
$\mathbf{1 6}$ & $1.4 \pm 0.02$ & $1.4 \pm 0.02$ & $\mathbf{1 5}$ \\
$\mathbf{1 7}$ & $1.3 \pm 0.01$ & $1.3 \pm 0.005$ & $\mathbf{1 5}$ and $\mathbf{1 4}$ \\
$\mathbf{2 0}$ & $0.9 \pm 0.004$ & $0.7 \pm 0.01$ & - \\
$\mathbf{2 2}$ & $1.3 \pm 0.01$ & $0.9 \pm 0.01$ & - \\
\hline
\end{tabular}

a HLMs: human liver microsomes; ${ }^{\mathrm{b}}$ MLMs: mouse liver microsomes. ${ }^{\mathrm{c}}$ Data from ref [21].

\subsection{Molecular Modeling}

To analyze the observed SAR for pyridine and imidazole based chemotype 2 and chemotype 3, molecular modeling of key ligands was performed on the crystal structure of PF74 bound to native HIV-1 capsid protein (PDB code: 4XFZ [17]). Both (S)-configuredpyridine and -imidazole based analogs 9 and 20 were predicted to occupy the PF74 binding pocket, superimpose well with PF74, and interact with similar amino acid residues of the HIV-1 capsid protein (Figure 4A). The inhibitory activities of compounds $9\left(\mathrm{EC}_{50}: 2.6 \mu \mathrm{M}\right)$ 
and $20\left(\mathrm{EC}_{50}: 3.7 \mu \mathrm{M}\right)$ can be attributed to their backbone resemblance to, and common key interactions with PF74 $\left(\mathrm{EC}_{50}: 0.7 \mu \mathrm{M}\right)$, including (i) H-bonding between indole $\mathrm{NH}$ of compounds 9, 20 and PF74 with Q63; (ii) cation- $\pi$ interaction of the indole ring of the three compounds with protonated K70; (iii) H-bonding between the indole acetic acid carbonyl group and K70; and (iv) H-bonding between NH and carbonyl group of phenylalanine moiety of PF74 and terminal amide group of N57. The absence of phenylalanine carbonylO4 and N57 hydrogen-bonding in compounds $\mathbf{9}$ and 20 is likely to be partially compensated for by the bonding between the nitrogen atom of pyridine and imidazole rings and terminal amide of N57 (Figure 4A). A complete loss of potency was observed in the case of $(R)$ configured-pyridine based analog $4\left(\mathrm{EC}_{50} \mu \mathrm{M}\right.$ : $>20$ for 4 vs. 2.6 for its $(S)$-configured analog 9). This is presumably because the benzyl group of compound 4 (circled) is expected to point away from the PF74-cavity, resulting in loss of hydrophobic interactions with M66 and other hydrophobic amino acid residues (Figure 4B). That, in turn, may lead to loss of the key H-bonding interaction between pyridine ring nitrogen atom and N57 (Figure 4B). Halogen-bonding was evident in current SAR as compound $\mathbf{1 3}$ showed a four-fold increase in potency compared to its non-halogen analog 9 ( $\mathrm{EC}_{50} \mu \mathrm{M}$ : 0.79 for $13 \mathrm{vs}$. 2.6 for 9). In addition, the 5-hydroxy substitution on the indole ring of the pyridine analog $\mathbf{1 5}$ further enhanced antiviral potency 12- and 2-fold in comparison with compounds 9, 13, and PF74 (EC $50 \mu \mathrm{M}$ : 0.31 for 15 vs. 0.7 for PF74 vs. 0.79 for 13 vs. 2.6 for 9). This increased potency can be attributed to the potential H-bonding by the $\mathrm{OH}$ of compound $\mathbf{1 5}$ to residue K182 on the adjacent $\mathrm{CA}_{\mathrm{CTD}}$ (Figure $4 \mathrm{C}$ ).

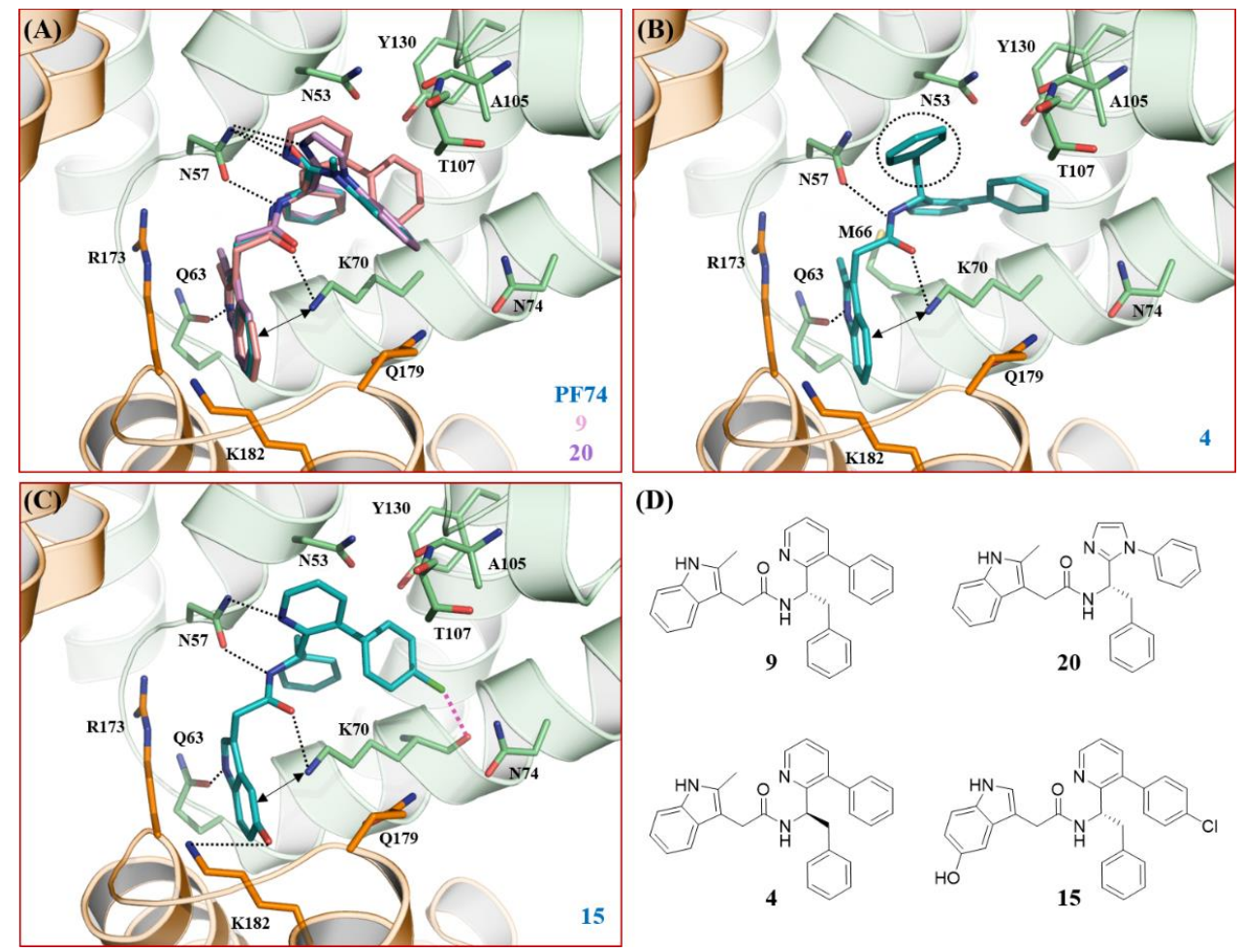

Figure 4. Docking poses of key ligands based on native HIV-1 capsid protein bound to PF74 (PDB code: 4XFZ [17]). (A) Superimposition of PF74 and compounds 9 and 20 depicting binding similarity to PF74 and the fitting of compounds 9 and 20 within the PF74 binding pocket. Glide scores (kcal/mol): -5.6 (PF74); -6.1 (9); - 5.3 (20); (B) predicted binding mode of 4 in which the benzyl group (circled) of the phenylalanine fragment points away from the hydrophobic pocket around residue M66. Glide score (kcal/mol): -3.7; (C) predicted binding of analog 15 within the preferred PF74 binding cavity showing additional $\mathrm{H}$ - and halogen-bonding with $\mathrm{K} 182$ and $\mathrm{K} 70$, respectively. Glide score (kcal/mol): -7.7; (D) chemical structures of compounds 4, 9, 15 and 20. H-bond, halogen-bond and cation- $\pi$ interactions are depicted as black dotted lines, pink dotted line and double headed arrow, respectively. $\mathrm{CA}_{\mathrm{NTD}}$ around $\mathrm{H} 3$ and H4, and CA $\mathrm{C}_{\mathrm{CD}}$ around H8 and H9 are colored green and orange, respectively. The nitrogen, oxygen, sulfur, and chlorine atoms are colored blue, red, yellow, and green, respectively. 


\section{Discussion}

PF74 is a phenylalanine-derived peptidomimetic with a well-defined binding mode to $\mathrm{CA}$ and sub-micromolar antiviral activity. Although mechanistically unique and synthetically highly accessible, PF74 is far less potent than GS-6207 and exceedingly unstable toward CYP-mediated oxidative metabolism. The three series of analogs (chemotypes 1-3, Figure 2) designed and synthesized in this study feature different forms of conformational restrictions of the PF74 backbone to improve antiviral potency and increased metabolic stability. Notably, both modifications (cyclization patterns A and B, Figure 2) involved altering the aniline $N$-methyl of PF74, which forms a key van der Waals interaction with the N53 required for the potency of the parent PF74 as per previously reported SAR [20]. Consistent with this SAR observation, modification A yielded compounds (chemotype 1) without appreciable antiviral activity or CA-stabilizing/destabilizing effect (Table 1). By contrast, modification B (Figure 2) is apparently tolerated as the resulting pyridine (chemotype 2) and imidazole (chemotype 3 ) series both contain compounds with significant antiviral activity and strong CA-stabilizing effect (Tables 2 and 3), suggesting that the loss of the van der Waals interaction can be compensated for with modification $B$ (chemotype 2 and chemotype 3) but not modification A (chemotype 1). As for modification B, while the SAR of the imidazole series (Table 3) was largely flat with the exception of the inactive analog 22, the pyridine series displayed prominent SAR trends where both the antiviral potency and the CA-stabilizing effect were highly dependent on the $S$-configured phenylalanine moiety as well as the indole ring (Table 2).

Another important aim of the current work is to identify and avoid structural features with potential metabolic liability to improve metabolic stability. As mentioned earlier, the aniline $\mathrm{N}$-methyl group of PF74 is highly susceptible toward oxidative metabolism. However, designing out this $N$-methyl group using a pyridine $(\mathbf{9}, \mathbf{1 4}, \mathbf{1 6}-\mathbf{1 7}$, Table 4$)$ or imidazole (20, 22) ring did not lead to significantly improved metabolic stability (Table 4). In the meantime, we have previously shown that replacing the electron-rich and easily oxidizable indole ring with less electron-rich ring systems could largely mitigate the metabolic liability [22,23]. Intriguingly, when an electron-donating hydroxyl group was introduced onto the C5 position of the indole ring, the resulting analog 15 showed drastically improved metabolic stability, despite being more electron-rich. This is presumably because the major oxidative metabolic pathway of the indole ring features a hydroxylation at the C5 position [46] as exemplified by the well-known conversion of tryptophan to serotonin [47]. Consistent with this metabolic pathway, 15 was also observed as a stable metabolite of 14,16 and 17. The proposed metabolic pathways are described in Figure 5. The conversion of $\mathbf{1 6}$ to $\mathbf{1 5}$ likely entails a $\mathrm{C} 5$ hydroxylation and a de-ethylation at the indole $\mathrm{N}$ via $\alpha$-carbon hydroxylation, followed by the collapse of the hemiaminal in 16b. A similar hydroxylation of $\mathbf{1 7}$ could generate 14, which was indeed observed as a metabolite of $\mathbf{1 7}$. The de-methylation of the OMe group in $\mathbf{1 4}$ is likely via a hemiacetal intermediate 14a produced by the $\alpha$-carbon hydroxylation of the OMe. It is noteworthy that CYP-mediated de-alkylation is well-known [48]. 
<smiles>CCn1cc(CC(=O)N[C@H](Cc2ccccc2)c2ncccc2-c2ccc(Cl)cc2)c2cc(OC)ccc21</smiles><smiles>CCn1cc(CC(=O)N[C@H](Cc2ccccc2)c2ncccc2-c2ccc(Cl)cc2)c2ccccc21</smiles><smiles>CC(C)(C)c1ccccc1CC(=O)N[C@H](c1ccc(Cl)cc1)c1cccnc1CCc1c[nH]c2ccc(OCO)cc12</smiles><smiles>CCn1cc(CC(=O)N[C@@H](Cc2ccccc2)c2ncccc2-c2ccc(Cl)cc2)c2cc(O)ccc21</smiles><smiles>CCOCCN(Cc1ccccc1)c1ncccc1-c1ccc(Cl)cc1</smiles>

Figure 5. Proposed metabolic pathways of 17, 14 and 16 toward 15. Major cyclophilin- (CYP)-mediated oxidative reactions include oxidative O-de-methylation and N-de-ethylation, and $5^{\prime}$-hydroxylation of the indole ring.

\section{Conclusions}

To identify novel small molecules targeting the PF74 binding site of HIV-1 CA, we designed, synthesized and characterized three chemotypes featuring different conformational constraints. Through subsequent SAR, we identified analog 15 which displayed potent antiviral activity against HIV-1 $\left(\mathrm{EC}_{50}=0.31 \mu \mathrm{M}\right)$, strong CA-stabilizing effect $\left(\Delta \mathrm{Tm}=8.7^{\circ} \mathrm{C}\right)$, and drastically improved metabolic stability $\left(\mathrm{t}_{1 / 2}=27 \mathrm{~min}\right)$. The observed metabolic pathways also suggest that blocking the $\mathrm{C} 5$ position of the indole ring may represent an important approach to metabolically stable PF74 analogs.

Supplementary Materials: The following are available online at https:/ / www.mdpi.com/1999-4 915/13/3/479/s1, Scheme S1: synthesis of intermediates 27-28 and compounds 1-3, Scheme S2: synthesis of intermediates 30-37 and compounds 4-19, Scheme S3: synthesis of intermediates 39-41 and compounds 20-25.

Author Contributions: S.G.S. and Z.W. conceptualized the research. R.L.S. and R.D.-R. designed, synthesized and characterized all compounds, with the help of S.K.V.V. and L.W., R.L.S. conducted all modeling. J.X. performed the microsomal stability assays. H.D., H.Z., A.E.C., M.C.C., K.A.K., and P.R.T. performed and/or evaluated data from TSA, antiviral, and cytotoxicity assays. R.L.S. and Z.W. wrote the manuscript. K.A.K. and P.R.T. edited the manuscript. All authors have read and agreed to the published version of the manuscript.

Funding: This research was funded by the National Institute of Allergy and Infectious Diseases (NIAID) at the National Institutes of Health (NIH), grant number R01AI120860 (to S.G.S. and Z.W.). S.G.S. acknowledges funding from the Nahmias-Schinazi Distinguished Chair in Research.

Institutional Review Board Statement: Not applicable.

Informed Consent Statement: Not applicable.

Data Availability Statement: The data presented in this study are Supplementary Materials.

Acknowledgments: We thank the Minnesota Supercomputing Institute (MSI) at the University of Minnesota for providing molecular modeling resources.

Conflicts of Interest: The authors declare no conflict of interest. 


\section{References}

1. Novikova, M.; Zhang, Y.; Freed, E.O.; Peng, K. Multiple Roles of HIV-1 Capsid during the Virus Replication Cycle. Virol. Sin. 2019, 34, 119-134. [CrossRef]

2. Freed, E.O. HIV-1 assembly, release and maturation. Nat. Rev. Microbiol. 2015, 13, 484-496. [CrossRef]

3. Buffone, C.; Martinez-Lopez, A.; Fricke, T.; Opp, S.; Severgnini, M.; Cifola, I.; Petiti, L.; Frabetti, S.; Skorupka, K.; Zadrozny, K.K.; et al. Nup153 Unlocks the Nuclear Pore Complex for HIV-1 Nuclear Translocation in Nondividing Cells. J. Virol. 2018, 92, e00648-18. [CrossRef]

4. Chin, C.R.; Perreira, J.M.; Savidis, G.; Portmann, J.M.; Aker, A.M.; Feeley, E.M.; Smith, M.C.; Brass, A.L. Direct Visualization of HIV-1 Replication Intermediates Shows that Capsid and CPSF6 Modulate HIV-1 Intra-nuclear Invasion and Integration. Cell Rep. 2015, 13, 1717-1731. [CrossRef]

5. Bejarano, D.A.; Peng, K.; Laketa, V.; Börner, K.; Jost, K.L.; Lucic, B.; Glass, B.; Lusic, M.; Müller, B.; Kräusslich, H.-G. HIV-1 nuclear import in macrophages is regulated by CPSF6-capsid interactions at the nuclear pore complex. eLife 2019, 8, e41800. [CrossRef]

6. Sowd, G.A.; Serrao, E.; Wang, H.; Wang, W.; Fadel, H.J.; Poeschla, E.M.; Engelman, A.N. A critical role for alternative polyadenylation factor CPSF6 in targeting HIV-1 integration to transcriptionally active chromatin. Proc. Natl. Acad. Sci. USA 2016, 113, E1054-E1063. [CrossRef] [PubMed]

7. Achuthan, V.; Perreira, J.M.; Sowd, G.A.; Puray-Chavez, M.; McDougall, W.M.; Paulucci-Holthauzen, A.; Wu, X.; Fadel, H.J.; Poeschla, E.M.; Multani, A.S.; et al. Capsid-CPSF6 Interaction Licenses Nuclear HIV-1 Trafficking to Sites of Viral DNA Integration. Cell Host Microbe 2018, 24, 392-404. [CrossRef] [PubMed]

8. Kim, K.; Dauphin, A.; Komurlu, S.; McCauley, S.M.; Yurkovetskiy, L.; Carbone, C.; Diehl, W.E.; Strambio-De-Castillia, C.; Campbell, E.M.; Luban, J. Cyclophilin A protects HIV-1 from restriction by human TRIM5 $\alpha$. Nat. Microbiol. 2019, 4, $2044-2051$. [CrossRef] [PubMed]

9. Carnes, S.K.; Sheehan, J.H.; Aiken, C. Inhibitors of the HIV-1 capsid, a target of opportunity. Curr. Opin. HIV AIDS 2018, 13, 359-365. [CrossRef]

10. Lamorte, L.; Titolo, S.; Lemke, C.T.; Goudreau, N.; Mercier, J.-F.; Wardrop, E.; Shah, V.B.; von Schwedler, U.K.; Langelier, C.; Banik, S.S.R.; et al. Discovery of Novel Small-Molecule HIV-1 Replication Inhibitors That Stabilize Capsid Complexes. Antimicrob. Agents Chemother. 2013, 57, 4622-4631. [CrossRef] [PubMed]

11. Lemke, C.T.; Titolo, S.; von Schwedler, U.; Goudreau, N.; Mercier, J.-F.; Wardrop, E.; Faucher, A.-M.; Coulombe, R.; Banik, S.S.R.; Fader, L.; et al. Distinct Effects of Two HIV-1 Capsid Assembly Inhibitor Families That Bind the Same Site within the N-Terminal Domain of the Viral CA Protein. J. Virol. 2012, 86, 6643. [CrossRef] [PubMed]

12. Kelly, B.N.; Kyere, S.; Kinde, I.; Tang, C.; Howard, B.R.; Robinson, H.; Sundquist, W.I.; Summers, M.F.; Hill, C.P. Structure of the Antiviral Assembly Inhibitor CAP-1 Complex with the HIV-1 CA Protein. J. Mol. Biol. 2007, 373, 355-366. [CrossRef] [PubMed]

13. Blair, W.S.; Pickford, C.; Irving, S.L.; Brown, D.G.; Anderson, M.; Bazin, R.; Cao, J.; Ciaramella, G.; Isaacson, J.; Jackson, L.; et al. HIV Capsid is a Tractable Target for Small Molecule Therapeutic Intervention. PLoS Pathog. 2010, 6, e1001220. [CrossRef]

14. Link, J.O.; Rhee, M.S.; Tse, W.C.; Zheng, J.; Somoza, J.R.; Rowe, W.; Begley, R.; Chiu, A.; Mulato, A.; Hansen, D.; et al. Clinical targeting of HIV capsid protein with a long-acting small molecule. Nature 2020, 584, 614-618. [CrossRef] [PubMed]

15. Bester, S.M.; Wei, G.; Zhao, H.; Adu-Ampratwum, D.; Iqbal, N.; Courouble, V.V.; Francis, A.C.; Annamalai, A.S.; Singh, P.K.; Shkriabai, N.; et al. Structural and mechanistic bases for a potent HIV-1 capsid inhibitor. Science 2020, 370, 360. [CrossRef]

16. Pornillos, O.; Ganser-Pornillos, B.K.; Yeager, M. Atomic-level modelling of the HIV capsid. Nature 2011, 469, 424-427. [CrossRef]

17. Gres, A.T.; Kirby, K.A.; KewalRamani, V.N.; Tanner, J.J.; Pornillos, O.; Sarafianos, S.G. X-ray crystal structures of native HIV-1 capsid protein reveal conformational variability. Science 2015, 349, 99. [CrossRef] [PubMed]

18. Price, A.J.; Jacques, D.A.; McEwan, W.A.; Fletcher, A.J.; Essig, S.; Chin, J.W.; Halambage, U.D.; Aiken, C.; James, L.C. Host Cofactors and Pharmacologic Ligands Share an Essential Interface in HIV-1 Capsid That Is Lost upon Disassembly. PLoS Pathog. 2014, 10, e1004459. [CrossRef]

19. Kleinpeter, A.B.; Freed, E.O. HIV-1 Maturation: Lessons Learned from Inhibitors. Viruses 2020, 12, 940. [CrossRef]

20. Wang, L.; Casey, M.C.; Vernekar, S.K.V.; Do, H.T.; Sahani, R.L.; Kirby, K.A.; Du, H.; Hachiya, A.; Zhang, H.; Tedbury, P.R.; et al. Chemical profiling of HIV-1 capsid-targeting antiviral PF74. Eur. J. Med. Chem. 2020, 200, 112427. [CrossRef]

21. Vernekar, S.K.V.; Sahani, R.L.; Casey, M.C.; Kankanala, J.; Wang, L.; Kirby, K.A.; Du, H.; Zhang, H.; Tedbury, P.R.; Xie, J.; et al. Toward Structurally Novel and Metabolically Stable HIV-1 Capsid-Targeting Small Molecules. Viruses 2020, 12, 452. [CrossRef]

22. Wang, L.; Casey, M.C.; Vernekar, S.K.V.; Sahani, R.L.; Kankanala, J.; Kirby, K.A.; Du, H.; Hachiya, A.; Zhang, H.; Tedbury, P.R.; et al. Novel HIV-1 capsid-targeting small molecules of the PF74 binding site. Eur. J. Med. Chem. 2020, 204, 112626. [CrossRef]

23. Wang, L.; Casey, M.C.; Vernekar, S.K.V.; Sahani, R.L.; Kirby, K.A.; Du, H.; Zhang, H.; Tedbury, P.R.; Xie, J.; Sarafianos, S.G.; et al. Novel PF74-like small molecules targeting the HIV-1 capsid protein: Balance of potency and metabolic stability. Acta Pharm. Sin. B 2020. [CrossRef]

24. Chang, C.E.A.; Chen, W.; Gilson, M.K. Ligand configurational entropy and protein binding. Proc. Natl. Acad. Sci. USA 2007, 104, 1534. [CrossRef]

25. Lawson, A.D.G.; MacCoss, M.; Heer, J.P. Importance of Rigidity in Designing Small Molecule Drugs To Tackle Protein-Protein Interactions (PPIs) through Stabilization of Desired Conformers. J. Med. Chem. 2018, 61, 4283-4289. [CrossRef] [PubMed] 
26. Borsari, C.; Rageot, D.; Dall'Asen, A.; Bohnacker, T.; Melone, A.; Sele, A.M.; Jackson, E.; Langlois, J.-B.; Beaufils, F.; Hebeisen, P.; et al. A Conformational Restriction Strategy for the Identification of a Highly Selective Pyrimido-pyrrolo-oxazine mTOR Inhibitor. J. Med. Chem. 2019, 62, 8609-8630. [CrossRef]

27. Kedderis, G.L.; Hollenberg, P.F. Peroxidase-catalyzed N-demethylation reactions: Deuterium solvent isotope effects. Biochemistry 1985, 24, 6158-6163. [CrossRef] [PubMed]

28. Hollenberg, P.F.; Miwa, G.T.; Walsh, J.S.; Dwyer, L.A.; Rickert, D.E.; Kedderis, G.L. Mechanisms of N-demethylation reactions catalyzed by cytochrome P-450 and peroxidases. Drug Metab. Dispos. 1985, 13, 272. [PubMed]

29. Bondy, S.S.; Cannizzaro, C.E.; Chou, C.-H.; Halcomb, R.L.; Hu, E.Y.; Link, J.O.; Liu, Q.; Schroeder, S.D.; Tse, W.C.; Zhang, J.R. Compounds for the treatment of HIV. Patent WO 2013/006738 A1, 1 October 2013.

30. Belema, M.; Bender, J.A.; Beno, B.; Gentles, R.G.; Li, G.; Meanwell, N.A.; Pendri, A.; Yang, Z.; Zhu, S. Inhibitors of Human Immunodeficiency Virus Replication. U.S. Patent 2017/0304239 A1, 27 November 2017.

31. Lange, M.J.; Lyddon, T.D.; Johnson, M.C. Diphtheria Toxin A-Resistant Cell Lines Enable Robust Production and Evaluation of DTA-Encoding Lentiviruses. Sci. Rep. 2019, 9, 8985. [CrossRef]

32. Rosa, A.; Chande, A.; Ziglio, S.; De Sanctis, V.; Bertorelli, R.; Goh, S.L.; McCauley, S.M.; Nowosielska, A.; Antonarakis, S.E.; Luban, J.; et al. HIV-1 Nef promotes infection by excluding SERINC5 from virion incorporation. Nature 2015, 526, 212-217. [CrossRef]

33. Pornillos, O.; Ganser-Pornillos, B.K.; Kelly, B.N.; Hua, Y.; Whitby, F.G.; Stout, C.D.; Sundquist, W.I.; Hill, C.P.; Yeager, M. X-Ray Structures of the Hexameric Building Block of the HIV Capsid. Cell 2009, 137, 1282-1292. [CrossRef]

34. Adachi, A.; Gendelman, H.E.; Koenig, S.; Folks, T.; Willey, R.; Rabson, A.; Martin, M.A. Production of acquired immunodeficiency syndrome-associated retrovirus in human and nonhuman cells transfected with an infectious molecular clone. J. Virol. 1986, 59, 284. [CrossRef]

35. Schrödinger. Schrödinger Small-Molecule Drug Discovery Suite 2019-4; Schrödinger, LLC: New York, NY, USA, 2019.

36. Schrödinger. Schrödinger Release 2019-4: Maestro; Schrödinger, LLC: New York, NY, USA, 2019.

37. Schrödinger. The PyMOL Molecular Graphics System; Version 2.0; Schrödinger, LLC: New York, NY, USA, 2019.

38. Sastry, G.M.; Adzhigirey, M.; Day, T.; Annabhimoju, R.; Sherman, W. Protein and ligand preparation: Parameters, protocols, and influence on virtual screening enrichments. J. Comput. Aided Mol. Des. 2013, 27, 221-234. [CrossRef] [PubMed]

39. Jorgensen, W.L.; Maxwell, D.S.; Tirado-Rives, J. Development and Testing of the OPLS All-Atom Force Field on Conformational Energetics and Properties of Organic Liquids. J. Am. Chem. Soc. 1996, 118, 11225-11236. [CrossRef]

40. Friesner, R.A.; Murphy, R.B.; Repasky, M.P.; Frye, L.L.; Greenwood, J.R.; Halgren, T.A.; Sanschagrin, P.C.; Mainz, D.T. Extra Precision Glide: Docking and Scoring Incorporating a Model of Hydrophobic Enclosure for Protein-Ligand Complexes. J. Med. Chem. 2006, 49, 6177-6196. [CrossRef]

41. Singh, K.; Gallazzi, F.; Hill, K.J.; Burke, D.H.; Lange, M.J.; Quinn, T.P.; Neogi, U.; Sönnerborg, A. GS-CA Compounds: First-In-Class HIV-1 Capsid Inhibitors Covering Multiple Grounds. Front. Microbiol. 2019, 10. [CrossRef]

42. Xu, J.P.; Francis, A.C.; Meuser, M.E.; Mankowski, M.; Ptak, R.G.; Rashad, A.A.; Melikyan, G.B.; Cocklin, S. Exploring Modifications of an HIV-1 Capsid Inhibitor: Design, Synthesis, and Mechanism of Action. J. Drug Des. Res. 2018, 5, 1070. [PubMed]

43. Sun, L.; Huang, T.; Dick, A.; Meuser, M.E.; Zalloum, W.A.; Chen, C.-H.; Ding, X.; Gao, P.; Cocklin, S.; Lee, K.-H.; et al. Design, synthesis and structure-activity relationships of 4-phenyl-1H-1,2,3-triazole phenylalanine derivatives as novel HIV-1 capsid inhibitors with promising antiviral activities. Eur. J. Med. Chem. 2020, 190, 112085. [CrossRef] [PubMed]

44. Wu, G.; Zalloum, W.A.; Meuser, M.E.; Jing, L.; Kang, D.; Chen, C.-H.; Tian, Y.; Zhang, F.; Cocklin, S.; Lee, K.-H.; et al. Discovery of phenylalanine derivatives as potent HIV-1 capsid inhibitors from click chemistry-based compound library. Eur. J. Med. Chem. 2018, 158, 478-492. [CrossRef] [PubMed]

45. Wacher, V.J.; Silverman, J.A.; Zhang, Y.; Benet, L.Z. Role of P-Glycoprotein and Cytochrome P450 3A in Limiting Oral Absorption of Peptides and Peptidomimetics. J. Pharm. Sci. 1998, 87, 1322-1330. [CrossRef] [PubMed]

46. Pavlova, T.; Vidova, V.; Bienertova-Vasku, J.; Janku, P.; Almasi, M.; Klanova, J.; Spacil, Z. Urinary intermediates of tryptophan as indicators of the gut microbial metabolism. Anal. Chim. Acta 2017, 987, 72-80. [CrossRef] [PubMed]

47. Höglund, E.; Øverli, Ø.; Winberg, S. Tryptophan Metabolic Pathways and Brain Serotonergic Activity: A Comparative Review. Front. Endocrinol. 2019, 10. [CrossRef] [PubMed]

48. Hesse, L.M.; Venkatakrishnan, K.; von Moltke, L.L.; Shader, R.I.; Greenblatt, D.J. CYP3A4 Is the Major CYP Isoform Mediating the in Vitro Hydroxylation and Demethylation of Flunitrazepam. Drug Metab. Dispos. 2001, 29, 133. [PubMed] 